\title{
Буддийские мотивы в фольклоре (на материале калмыцких, тувинских и бурятских эпических произведений и богатырских сказок)
}

\author{
Алексей А. Бурыкин \\ Калмыцкий научный центр Российской академии наук, Российская Федерация
}

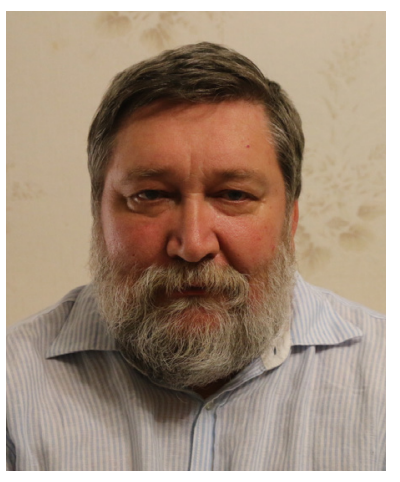

Статья содержит опыт рассмотрения художественного пространства и топонимов, характерных для буддийских сочинений, поскольку буддийское вероучение распространено как среди тувинцев, так и среди монголов, бурят, ойратов и калмыков. Объектом исследования также являются фольклорные тексты, представляющие образцы героического эпоса и сказок, преимущественно богатырских.

Автор анализирует исследования, посвященные отражению компонентов буддийского вероучения и культа в калмыцком, тувинском и бурятском фольклоре. Устанавливается, что к буддийским компонентам фольклора относится упоминание горы Сумеру, названия божеств, отдельных реалий, в том числе книжных сочинений и молитв, описания ритуалов как элемент повседневной практики. Некоторые современные топонимы Тувы имеют прямые соответствия в одной из версий калмыцкого эпоса «Джангар», что расширяет объем реальных местностей как компонентов пространства калмыцкого героического эпоса.

В цеелом буддийские элементы в устных фольклорных традициях народов, исповедующих буддизм, представляют упоминания сакральных объектов, имен божеств, названий буддийских сочинений и тексты молитв, описания ритуалов в контексте практики повседневной деятельности.

Ключевые слова: буддизм; топоним; богатырская сказка; эпический текст; калмыки; тувинцы; буряты; калмыцкий фольклор; тувинский фольклор; бурятский фольклор

Исследование проведено в рамках государственной субсидии - проект «Фольклор монголоязычных народов: тексты и исследования» (регистрационный номер АААA-А17-117030910099-8).

\section{Для цитирования:}

Бурыкин А. А. Буддийские мотивы в фольклоре (на материале калмыцких, тувинских и бурятских эпических произведений и богатырских сказок) // Новые исследования Тувы. 2020, № 3. С. 189-209. DOI: www.doi. org/10.25178/nit.2020.3.14

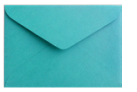

Бурыкин Алексей Алексеевич - доктор филологических наук, доктор исторических наук, ведущий научный сотрудник отдела фольклора и литературы Калмыцкого научного центра РАН. Адрес: 358000, Россия, г. Элиста, ул. И. К. Илишкина, д. 8. Тел.: +7 (911) 709-14-76. Эл. адрес: albury@mail.ru

BURYKIN, Aleksey Alekseevich, Doctor of Philology, Doctor of History, Leading Research Associate, Department of Folklore and Literature, Kalmyk Scientific Center of the Russian Academy of Sciences. Postal address: 8 Ilishkin St., 358000 Elista, Russian Federation. Tel.: +7 (911) 709-14-76. E-mail: albury@mail.ru ORCID ID: 0000-0002-0398-4792 


\title{
Buddhist motifs in folklore: the case of Kalmyk, Tuvan and Buryat epics and heroic tales
}

\author{
Alexey A. Burykin \\ Kalmyk Scientific Centre, Russian Academy of Sciences, Russian Federation
}

The article examines the textual space and toponyms that are typical for Buddhist works, since Buddhist faith is widespread among Tuvans, as well as the Mongols, Buryats, Oirats and Kalmyks. Our study also focuses on folklore texts in the genres of heroic epics and fairy tales, primarily also dealing with heroes' deeds.

The author analyses works wherein the Buddhist faith and cult found a reflection in Kalmyk, Tuvan and Buryat folklore. The components of these Buddhist reflections have been found to include mount Sumeru, the names of deities, specific realities, including books and prayers, and descriptions of rituals as an element of everyday practice. Some modern Tuvan toponyms have direct correspondences in one of the versions of the Kalmyk epic 'Dzhangar', which expands the geography of the Kalmyck heroic epics to cover more real locations.

Overall, Buddhist elements in the oral folklore of peoples professing Buddhism include references to sacred objects, names of deities, names of Buddhist writings and prayer texts, and descriptions of rituals in the context of daily practice.

Keywords: Buddhism; toponym; heroic fairy tale; epic text; Kalmyks; Tuvans; Buryats; Kalmyk folklore; Tuvan folklore; Buryat folklore

Financing

This work was carried out within the framework of the state subsidy - the project "Folklore of Mongolian-speaking peoples: texts and studies" (registration no. AAAA-A17-117030910099-8).

\section{For citation:}

Burykin A. A. Buddiiskie motivy v fol'klore (na materiale kalmytskikh, tuvinskikh i buriatskikh epicheskikh proizvedenii i bogatyrskikh skazok) [Buddhist motifs in folklore: the case of Kalmyk, Tuvan and Buryat epics and heroic tales]. New Research of Tuva, 2020, no. 3, pp. 189-209. (In Russ.). DOI: www.doi.org/10.25178/nit.2020.3.14

\section{Введение}

Буддизм, ставший одной из традиционных конфессий народов России (бурят, калмыков, тувинцев, некоторых групп алтайцев), оказал заметное влияние на их духовную культуру, на сложение религиозно-мифологических представлений, получил отражение в героическом эпосе этих народов. В связи с этим представляет интерес выявление общих элементов в фольклорных традициях калмыков, тувинцев и бурят, появившихся после принятия ими буддизма, а также выявление сходств между монголоязычными и тюркоязычными образцами фольклора в условиях особенно интенсивных тюркомонгольских языковых и этнокультурных контактов.

Каким образом проникали знания о буддийской вере к этим народам? Помимо того, что существовала практика миссионерских визитов буддийских учителей из признанных центров, а значит прямая передача всех сакральных знаний от учителя к ученикам и последователям, сложилась традиция совершения священнослужителями и мирянами паломничеств в святые места. История распространения буддизма среди народов России подробно рассмотрена в целом ряде работ (История буддизма ..., 2010; Бакаева, 2008b; Монгуш, 2001; Монгуш, 2008; Хомушку, 2006; Ванчикова, Чимитдоржин, 2006). Не раз отмечалось, что распространение буддийского знания, буддийского видения мира пришло к этим народам из Тибета, через Монголию.

Исследователей, в том числе и автора настоящей статьи, давно привлекала проблема отражения разнообразных компонентов буддизма в эпических текстах (Дарбакова, 1997; Бакаева, 2004; Борджа- 
нова, 2000; Бурыкин, 2003; Лиджиев, 2010; Бадгаев, 2014 и др.), причем это касается не только эпоса калмыков, тувинцев и бурят (Шойнжонов, 2008), но и эпического фольклора алтайцев (Торбоков, 2017). Эта многоаспектная тема рассматривалась с самых разных позиций: выяснялся вопрос, какова степень отображения буддизма в ойратском и калмыцком героическом эпосе (Борджанова, 2000; Поляев, 1978; Чингэлтэй, 2004; Бакаева, 2004), какие элементы буддийской религиозной практики и культуры находят отражение в фольклорных нарративах (Музраева, 2016; Донгак 2018) и т. п.

Упоминания о книгах и конкретных буддийских текстах, проникшие в фольклор, представляют особый интердисциплинарный интерес, поскольку свидетельствуют о распространенности тех или иных буддийских сочинений в среде, близкой к хранителям фольклора. Этот вопрос только недавно стал привлекать внимание специалистов по книжному эпосу и взаимодействию эпоса и книжной словесности (Дугаров, 2017), при этом, как показывают наши материалы, читающий эпический герой встречается не только в «Гесериаде» и алтайском эпосе (там же: 82-83), но у всех народов Центральной Азии, у которых распространен буддизм - у калмыков, тувинцев и бурят. В традиции тувинской словесности изучено воздействие литературных сборников с «обрамленными повестями» на устную фольклорную традицию (Донгак, 2004).

Нас в настоящей работе интересует следующий вопрос: какое влияние оказала буддийская картина мира на географический ландшафт эпических сказаний, богатырских сказок и несказочной прозы те рефлексы буддийской космографии и топографии, которые сохранялись, продолжали и продолжают существовать в топонимике территорий, где традиционно проживают тувинцы, буряты и где проживали калмыки, а также на буддийский антропонимикон фольклорных образцов?

Для выяснения вопроса о том, претерпел ли влияние буддизма топономастикон эпического фольклора калмыков, тувинцев и бурят, необходимо привлечение данных буддийской литературы, а также исследований, посвященных ей. Среди этих работ следует остановиться на классическом труде известного монголоведа О. М. Ковалевского «Буддийская космология» (Ковалевский, 1837). Так, О. М. Ковалевский подчеркивал, что «<...> почти вся религиозная Литература Буддистов (так у автора. - A. Б.) должна почитаться источником космологических сведений в пространном значении» (там же: 13). Он указывает на основные положения, составляющие основу буддийской космологии, согласно им «<...> вместо Всемогущего Бога принимают две первоначальные силы, т. е. дух и материю, от действия которых мир происходит, совершенствуется, разрушается и по истечении времени опять возрождается» (там же: 19). Ковалевский также описывает три мира, первый из которых «верхний есть обиталище духовного начала», лишенного всего материального, “второй, средний мир <...>, населенный существами духовными, но наслаждающимися жизнью”, и “третий, низший мир органический или мир явления духа в материи, к которому принадлежат не только все видимые одушевленные творения, но и духи земные, водяные и эфирные. Последний из них по-санскритски называется Сансара"» (там же: 22; курсив автора. - А. Б.). Весьма существенно, что О. М. Ковалевский дал описание основ мироздания в буддийском понимании так же, как оно выступает в добуддийских религиозных воззрениях народов Центральной Азии.

Источниковой базой выступили как наиболее авторитетные научные издания, так и популярные сборники калмыцкого, тувинского и бурятского фольклора: издания разных версий эпоса «Джангар» (Джангар, 1988; Джангар, 1990; Джангар, 1999), том Свода калмыцкого фольклора (Калмыцкие богатырские сказки, 2017), три тома образцов фольклора тувинцев из серии «Памятники фольклора народов Сибири и Дальнего востока» (Тувинские народные ..., 1994; Тувинские героические ..., 1997; Мифы, легенды, предания ..., 2010), издание сказок и преданий тувинцев Монголии (Сказки и предания, 1994), издание бурятского эпоса (Аламжи мэргэн, 1991) и издания бурятских сказок (Флоренсов, 1927; Бурятские народные ..., 1990; Бурятские волшебные ..., 1993; Бурятские народные ... , 2008).

Обращение к эпическим сказаниям калмыков, тувинцев и бурят не случайно. Помимо того, что эпосоведами за последние десятилетия проделана большая работа по изданию большого объема фольклорных эпических произведений из репертуара разных сказителей (Джангар, 1988, 1990, 1999; Тувинские героические ..., 1997; Аламжи мэргэн, 1991), исследователями было подмечено существование у тувинцев сюжета о Джангаре (Богда Чаңгар хан, 1973; Куулар, 2004). Н. Ц. Биткеев писал об этом факте: «В сентябре 1957 г. тувинский ученый Куулар Дорж в местечке Эн-Суг записал у сказителя Б.У. Балбыра следующий сюжет о Джангаре. Он посвящен подвигам сына Джангара Шилоол. Всё, что относится к подвигам Шил-оола, характерно и для других национальных версий. <...> В целом тувинская версия сказки „О Джангаре“- самостоятельный сюжет...» (Биткеев, 2011: 19; см. еще: 
Селеева, 2019: 135; Хабунова и др., 2019). В 2017 г. опубликованы две калмыцкие сказки на сюжеты эпоса «Джангар» и две сказочные версии фрагментов «Гэсэра» (Калмыцкие богатырские сказки, 2017).

Эпические тексты тувинцев выступали объектом историко-этнографического (Гребнев, 1960), лингвистического (Хертек, 2015), литературоведческого и текстологического анализа (Орус-оол, 2001). На материале героического эпоса разрабатывались вопросы традиционной космологии тувинцев (Мижит, 2010). Особый интерес вызывает проблема выявления истоков тенгрианства в эпическом тексте и фольклоре тувинцев в целом (Орус-оол, 2018), не остались без внимания и проблемы перевода эпического текста (Орус-оол, 2011). На новый уровень выходят эпосоведческие изыскания в связи с начавшейся работой по созданию электронной базы данных текстов героического эпоса (Ондар, 2016) и издания Свода калмыцкого фольклора (Манджиева, 2016).

Бурятский эпос и героические сказки были предметом постоянного внимания фольклористовбурятоведов и представителей бурятской фольклористики-носителей традиции с конца XIX - начала XX в., прежде всего с именем М. Н. Хангалова (1858-1918) (Хангалов, 2004: 81-215). Этими формами фольклора ученые занимались и в середине XX в. (Поппе, 1941). В настоящее время эпические формы бурятского фольклора рассмотрены в монографиях А. И. Уланова (Уланов, 1957, 1963), Н. О. Шаракшиновой (Шаракшинова, 1987), Б. С. Дугарова и Н. Н. Николаевой (Дугаров, Николаева, 2015), в последней работе прослеживается многомерная связь бурятского эпоса и этнической культуры бурят, вместе с тем вслед за классиками монголоведения эти авторы отмечают связь фольклорных текстов «Гесера» с его книжной версией (там же: 273-274). Есть работа по сравнению «Гэсэра» и «Джангара» (Цыбенова, 2000).

\section{Буддийская космология в хронотопе калмыцкого фольклора}

Несмотря на то, что традиционный взгляд на героический эпос побуждает по традиции считать его содержание, а также место и время действия вымыслом, тем не менее его топономастикон, то есть топонимы и личные имена неэпических персонажей, побуждает проанализировать него и соотнести с географической реальностью в истории калмыков и буддийской теонимией. Здесь следует упомянуть исследования, посвященные эпосу «Джангар» в интересующих нас аспектах (Очир-Горяев, 1978; Бакаева, 2008а; Лиджиев, 2010; Бадгаев, 2014). В этих работах рассматривается топографическая картина эпического повествования, в которой сочетаются собственно эпические топонимы - вероятно, некогда реальные, но уже незнакомые последнему поколению традиционных исполнителей песен «Джангара», и те топонимы, которые поддаются идентификации с современными географическими именами и локализации на местности.

Изучение топографии и топонимии мира фольклора, в частности эпоса - того, что можно назвать эпическим хронотопом, составляет весьма сложную проблему для фольклористов и специалистов по исторической этнографии, изучающих географический кругозор этноса. Во-первых, далеко не все фольклорные жанры содержат топонимический материал: например, русская волшебная сказка никак не характеризует локус начала действия, а для именования отдаленных мест обходится «Тридевятым царством. Тридесятым государством», в целом та же картина отражена в «Сказках» А. С. Пушкина, тонко подметившего эту особенность фольклорного нарративного жанра.

Описание хронотопа, то есть системы пространственных и временных ориентиров повествования, для калмыцкого эпоса «Джангар», признается одной из важных и приоритетных задач исследования эпического текста (Бурыкин, Басангова, 2014: 11). Опыт инвентаризации топонимов «Джангара» по малодербетской версии (Джангар, 1999), дает нам 18 эпических топонимов (Бурыкин, Басангова, 2014: 13-15). Похоже, что эти эпические географические названия - они все относятся к двум разрядам: гидронимы - названия рек и морей, и оронимы - названия гор - не будут иметь перспектив конкретной локализации на местности и привязки к реально существующим географическим объектам, хотя и здесь могут встретиться сюрпризы. Надо признать, что другие разряды имен собственных калмыцкого эпоса, например, имена богатырских коней, хорошо соотносятся с известными традициями имянаречения животных у калмыков, а личные имена эпических персонажей, прежде всего мужские имена - Джангар, Хонгор, Мингиян, Санал, Савар - вошли в современный калмыцкий антропонимикон в 1960-е гг. (Монраев, 2012: 90; Справочник ..., 1979: 226-257). Тем не менее некоторые гидронимы, встречающиеся в эпосе «Джангар» и выступающие в качестве маркеров эпического пространства, не только привлекают к себе внимание исследователей, но и связываются с конкретными географическими объектами - так, река Эрцес идентифицируется с рекой Иртыш, название которой 
часто встречается в средневековых исторических источниках и оно объясняется из кетского языка как Эрь-сесь «Соболиная река» (Бурыкин, 2013: 123-129): предельно близкая к этому форма и отражена в калмыцком фольклорном тексте.

Важнейший пространствообразующий топоним калмыцкого эпоса «Джангар» - это страна Бумба, где в словоупотреблении «страна» подразумевается и географическая область, и политическая отнесенность, поскольку данная область является областью владений, соответственно государством ее правителя Джангара.

Страна Бумба в песнях «Джангара» характеризуется как «Священно-прекрасная страна»; после того, как богатыри совершают свои подвиги, «Бумбайская страна, как и прежде, / В мире и благоденствии пребывает» (Джангар, 1988: 14, см. также 153). Эта богатырская страна Бумба имеет свой кличуран и знамя желто-пестрого цвета, в нее доставляют пленников и добычу; пленника метят тамгой бумбайской страны (Джангар, 1990: 262, 270, 317). Сам Джангар представляется идеальным правителем и устроителем государства:

«Вера в их Бумбайской стране
Подобно солнцу, сияет,
Мирское правление
Стало крепким, как скала.
Под покровительством хана Джангара
В счастье, блаженстве все пребывают» (там же: 288-289),
«<...> люди его ханства делают родовитыми сирот, бедных - богатыми» (Джангар, 1988: 44).

Мы уже отмечали, что образ страны Бумбы в калмыцком героическом эпосе «Джангар» оказывается довольно сложным. Наиболее архаические мотивы: связанные с этим образом, побуждают видеть в стране Бумбе средний мир - мир людей, противопоставляющийся по крайней мере двум иным мирам, населенным демонами (верхнему и нижнему), и только в некоторых контекстах это понятие суживается до определенной местности, которая имеет своего духа-хозяина, духа-покровителя (Бурыкин, Басангова, 2014: 38).

Самое интересное, на наш взгляд, заключено в том, что страна Бумба в «Джангаре» является не названием местности, а эпическим политонимом, названием государства - названием владений «Джангара». Место, где она расположена, имеет в эпосе топографическое обозначение в соответствии с буддийскими представлениями об устройстве - это Замбатиб, область мира, где живут люди. Толкование значения и объяснение происхождения названия эпической страны Бумбы связывается, с одной стороны, с религиозно-мифологической топонимией, с другой - со знакомыми реалиями буддийского культа. Традиционно считается, что это название возникло как контаминация из названия мифического океана Бум-дала и названия сосуда для священного нектара-аршана, изображение которого венчает буддийский храм. Это могло привести к закреплению за названием Бумба обозначения некоей пространственной сферы, все содержимое которой мыслится как сакрализованное, идеальное, возвышенное (там же: 33-34), хотя иногда наименование Замбатиб выступает как синоним страны Бумбы (там же: 14). Наше мнение, согласно которому государство Джангара является эпической утопией, своеобразной социальной мечтой народа, вписанной в религиозный контекст, подвергается критике (Овшинов, 2020).

Калмыцкий героический эпос «Джангар», прошедший длительную, не менее чем 580-летнюю историю, аккумулировал в себе разные фрагменты образов этнической культуры калмыков. В нем сохраняются, хотя не всегда идентифицируются добуддийские элементы (талисман-охранитель страны Бумбы в виде конской головы, почитание духа-хозяина местности Мингьяном: в поздних сказочных текстах дух-хозяин сменяется Белым Старцем (Музраева, 2016). Топография «Джангара» осложняется хурулами, к которым едут богатыри перед совершением подвигов и после возвращения, тот же Мингьян щедро одаривает ламу (Бурыкин, Басангова, 2014: 24). Упоминание Замбатиба и иных топонимов, локализация которых осложнена или невозможна, в эпосе получает особую смысловую роль - она сближает два мира, мир людей, носителей фольклорной традиции, и иные миры, унаследованные или принятые посредством религиозного вероучения. У калмыков на территории их проживания сложился пласт топонимии, отражающий их приверженность буддизму (Гедеева, 2013). В топонимической картине мира калмыков сохраняются идеи о горе Сумеру (Хабунова, Гедеева, Убушиева, 2018: 248), примерно в той же форме, которая прослеживается по материалам тувинского фольклора (см. далее). 
Хотя сказка как жанр не предполагает ни этнической, ни этнокультурной идентификации своих героев и изображаемого в ней мира, в калмыцких богатырских сказках встречаются, причем в заметном количестве, культуроидентифицирующие детали, относящиеся к традиционной религии калмыков буддизму. Что характерно для текстов - реалии, чуждые традиционному по жанровой природе сказки миру, в текстах никак не комментируются и по умолчанию предполагаются знакомыми слушателям. Приведем примеры:

«В предыдущей жизни старуха и старик это были, оказывается, - сказал. - Старик “Дорджи джодво” читал, - сказал» (Калмыцкие богатырские сказки, 2017: 251);

«Ехали-ехали, землю (где слышалось) “мингн зеевя”' миновали и прибыли в некое место. На одном из островов трава, (словно) говоря: “Ом мани падме хум”, - шелестит. “Наш отец именно этого ещё не видел”, - подумал он» (там же: 33);

«<...> Ту землю, (где слышалось) “мингн зеевя”, миновав, приехали на какой-то остров. А на том острове трава и камыш (словно говоря): “Ом мани падме хум”, - беспрестанно шумели. Решив, что наш отец именно этого не видел, вернулся он домой. Пришёл и рассказал (обо всем) отцу, (тот): “Моего дневного (пути та) земля”, - сказал» (там же: 35).

В этих фрагментах упоминается буддийская сутра, имеющая широчайшее распространение среди калмыков со времен принятия ими буддизма «Дорджи Джодва» (или «Алмазная сутра»), и самая известная из буддийских молитвенных формул «Ом мани падме хум» - мантра бодхисаттвы Авалокитешвары. Полагаем, что за счет таких приемов слушатели получают возможность отождествлять себя с участниками сказочного действа, или приближать себя к ним.

Детали повествования, связывающие сюжет с буддизмом и его культурным миром, встречаются в разнообразных сказочных текстах калмыков. ср: «Когда шёл он, слева послышались трогательно прекрасные звуки молитвенных песнопений. Пошёл он и пришёл к тому дереву. То было дерево бодхи» (там же: 235). Когда листья его соприкасались, то издавали такие прекрасные звуки. Как справедливо отмечено в комментарии к этому тексту, «<...> дерево бодхи, священное дерево, под которым, сидя в медитации, Будда достиг просветления на благо всех живых существ» (там же: 520). Мотив, имеющий отношение к жизнеописанию Будды, свидетельствует о фундаментальных знаниях буддийских повествований исполнителями сказок вплоть до момента записи цитируемого текста.

В ряде сказок встречаются элементы буддийской космографии, органично вписывающиеся в повествование: (там же: 171; 509, комментарий).

В трех сказочных текстах встречается наименование земли, находящейся, по представлениям буддистов, в центре мира, где живут люди и где полагается жить сказочным героям:

«- Я - дочь Луны, - сказала.

- Как же вы здесь оказались? - спросил (он). Три девушки ответили:

- Мы втроём раз в год на запад Замбатива ${ }^{2}$, к животворному белому океану, прилетали в облике лебедей и плавали. Эти трое братьев-мусов нас подстерегли и схватили» (там же: 65).

В этой сказке девушки, принимающие облик лебедей, прилетают на самый край своей страны, где они меняют свой облик и где живут враждебные им герои.

Во втором примере проясняется тот факт, что обитаемый центр мира Замбатив имеется в каждом из трех мифических и сказочных миров - не только в Среднем, где происходит действие во многих эпизодах, но и в Верхнем мире:

«- Откуда ты, девушка? - спросил Джангар.

- Я - девушка из верхнего Замбатива» (там же: 233).

Такое же устройство мира мы наблюдаем в «Джангаре», где у каждого хана есть своя страна Бумба и богатыри, имеющие имена, одинаковые с именами богатырей Джангара.

«“<...> Прозывают его так: криком своим Замбатив сотрясающий, неустанно бегущего молодого солового коня имеющий, из горных мест (происходящий) Уту Улан богатырь”, - так сказал» (там же: 469).

1 «Мингн зеевя» - начало молитвы, обращенной к Цзонхаве (Цонкапе) (1375-1419) - тибетскому религиозному деятелю, основателю школы гелук, являющейся историческим направлением буддизма, воспринятым народами России.

2 Замбатив - в буддийской космологии один из четырех материков мироздания, расположенный с южной стороны священной горы Сумеру (Калмыцкие богатырские сказки, 2017: 550). 
Третий пример, относящийся к Среднему миру, показывает, как в сказочном пространстве за счет силы голоса богатыря центр пространства связывается с его краями - периферией.

В двух калмыцких текстах упоминается сакральный предмет - камень-чиндамани ${ }^{1}$. В одном случае он фигурирует в формуле «Три сожаления», которую произносит богатырь: «Третье, о чём сожалею, в пяти шагах к югу от этого колодца (похожий на) голову коня драгоценный (камень) чиндамани зарытый лежит, о том, что как хозяин пользоваться им не смогу, сожалею. Вот три моих сожаления» (там же: 61). В другом случае он упоминается как предмет особой заботы сказочного героя: «Аг-Сахал Богдитин решил спать на улице, он улегся в телегу, драгоценный камень, похожий на голову коня, подложил под голову и уснул» (там же: 75). То, что священный камень чиндамани похож на голову коня, отнюдь не случайно: точно такой же камень, находящийся на середине реки, является талисманом, от которого зависит благополучие страны Джангара - страны Бумбы (Бурыкин, Басангова, 2014: 41). Любопытно, что в Туве есть топоним Аът-Баштыг-Хем ('с лошадиной головой река'). Считается, что река названа по месту в истоках, где совершался ритуал жертвоприношения в форме вывешивания лошадиной шкуры с головой (Ондар, 2007: 131), однако это название на редкость удачно сходится с характеристикой топографии эпоса «Джангар» (талисман в виде конской головы) и общим для народов Евразии почитанием антропоморфных и зооморфных природных объектов.

Для топонимии эпоса «Джангар» характерно противопоставление наименования земного мира как географического понятия - Замбатиб, в котором выделяется священная гора Сумеру, и политического образования - страны Бумбы. Получается, что калмыцкий фольклор сохранил тройственность Замбатиба: пространственный объект с тем же названием, как и герои с одинаковыми именами, по воззрениям калмыков, присутствует во всех трех мирах, отражаемых в фольклоре. Вместе с тем отдельные топонимы «Джангара» коррелируют с топографической или этнографической реальностью.

\section{Буддийская космология в топономастиконе тувинского фольклора}

Эпические сказания тувинцев не только сохранили классическую эпическую стихотворную форму исполнения, но и соединили разные мировоззренческие компоненты, свойственные этносу, буддийские мотивы и мотивы, связанные с шаманством. Конкуренция двух идеологий видна в эпическом тексте «Хунан-Кара», где герой использует буддийскую книгу сутру для гадания, а потом призывает шамана:

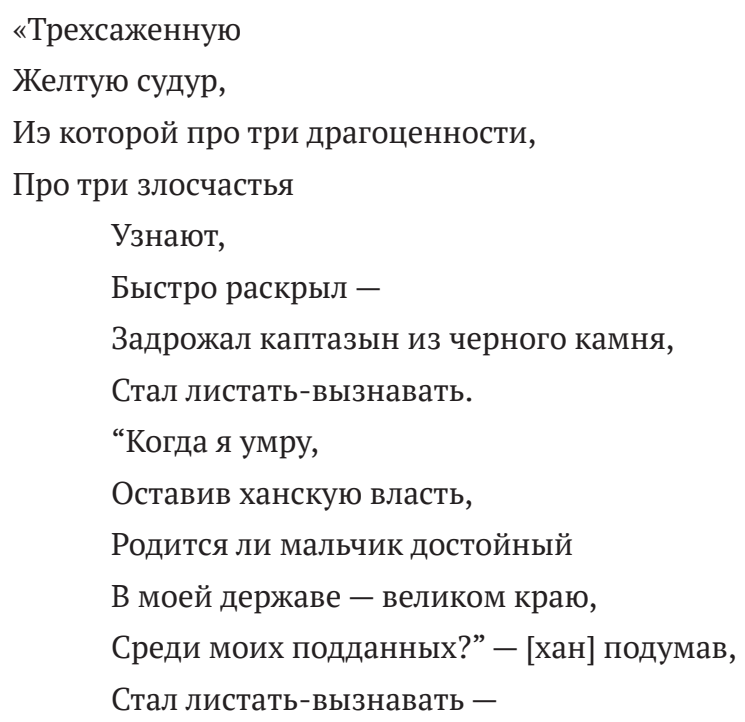

[Тогда] пригласили, привезли к ней

Эки-Хо-шамана,

Камлавшего в восточном краю.

Биение сердца проверил:

\footnotetext{
${ }^{1}$ Чиндамани - в буддийской мифологии драгоценный волшебный камень, исполняющий желания.
} 
“Самый разгар

Болезни" - сказал

Небесного цвета

Сиво-серого коня

Велел поймать,

Можжевельником стал окуривать, заклинать.

Но назавтра

Боли усилились.

Из [пещеры] Ак-Ой

Наставника-ламу

Пригласили к ней.

Наставник-лама приехал.

Гадальные кости бросил

“Это не разгар [болезни],

Предвещается что-то хорошее.

Даже вот что:

Счастье придет" -

На гадальных костях нагадал» (Тувинские героические сказания, 1997: 63).

В этом эпическом сказании упоминается главная географическая структура многих нарративов, связанных с буддизмом - местность Замбатиб, называемая сказителем Ямба-дип или Чамба-дип (там же: $95,127,131,135,137,211)$, в последнем эпизоде говорится о том, что задача скачек здесь - обежать семь раз вокруг Замбатиба-Ямба-дипа.

Нельзя не отметить того, что в этом сказании появляются образы буддийских божеств - Очур-баная (Очирвани, Ваджрапани) и Мага-халы (Махакалы, одного из воплощений Ваджрапани).

В сказании «Богтуг-Кириш, Бора-Шээлей» мы видим уже знакомую книгу-Судур, а также тойху стеклянное зеркало, гадательную практику на книге-сутре (там же: 299, 383, 473). В этом же сказании описано подношение бурхану:

«На трехсаженном шелковом хадаке-айыжы

Отборного черного соболя с белыми лапками

Бурхану поднес,/ Оказывается» (там же: 509-510).

Состязание богатырей в этом тексте изображено несколько иначе:

«“Передали, что через три дня будет состязание в беге”, - говорит

“За одну ночь Чамбы-дип обегаешь ты,

Бегущий Мерген, но как тут тебе быть?” - говорит» (там же: 383).

В одном из мифологических повествований как главный герой рассказа появляется Сагаан-Дарийги (Белая Тара) (Мижит, 2009: 177-178). По-видимому, такая ситуация, как явление буддийского божества в активной роли, характерно только для специализированных текстов, в эпических жанрах мы этого не встречаем.

В тувинских богатырских сказках буддийские мотивы присутствуют так же, как и в калмыцких богатырских сказках, однако практика их применения в текстах, на наш взгляд, оказывается несколько иной, нежели у калмыков. Материалом для данного раздела нашей работы явились записи Э. Таубе от алтайских тувинцев, живущих на территории Монголии (Сказки и предания ... , 1994), а также издания тувинских сказок и мифов.

Интересно, что образы Очирвани и Махакалы как характеристика внешнего облика человека в фольклоре тувинцев встречаются еще раз, то есть ведут себя как клише:

«На четырехножном ширэ

в дёре сидел

восьмилетний мальчик 


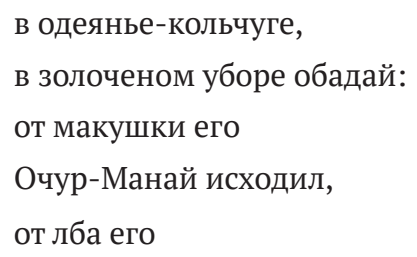

Мага-Хала бурган исходил» (Тувинские народные сказки, 1994: 69).

Еще одно буддийское божество, присутствующие в тувинских сказках - это Намзырай - Намсарай, Кубера, Дзамбала - бог богатства:

«Дальше поехали и приехали в аол-поселение Эрлик Ловун-хана.

Эрлик Ловун-хан сказал Бай-Белэди:

- Раз уж твои бесценные тысяча лан полудного золота осветили мой мир, стань самим Намзырайбурганом, - и хлопнул его ладонью по лбу.

И Бай-Белэди, став Намзырай-бурханом, зажил, ведая государственными делами, и писал в назидание историю» (там же, 1994: 305).

Слово бурхан, общее для тюркских и монгольских языков, обозначает и божество, и его изображение (Музраева, 2014).

Довольно много примечательных мотивов, связанных с буддизмом, встречается в несказочной прозе тувинцев. Это мотив, почему человек ходит на двух ногах: такова воля бурхана (Мифы, легенды ..., 2010: 47-49), рассказ о том, как Очурбаанай отправил Ара-хоо на Луну (там же: 53), рассказ о происхождении змеиного яда - ученики Будды пожалели змею (там же: 55), привлекает внимание рассказ о прародине тувинцев на реке Орхон (там же: 55). Нельзя не заметить почти традиционную для тувинцев тему конфликта щамана и служителя буддийского культа - таковы повествования «Рассказ про бай-Тайгу» (там же: 275-279) и «Состязание Ловуна-гадателя и шаманки» (там же: 173-176).

Некоторые образцы тувинских богатырских сказок насыщены буддийскими именами и реалиями: «Оба они стали добрыми друзьями, наши герои, призвав на свои головы защиту Балджыр Бургана, на свои косы - защиту Гесер Богды, а на свои темечки - защиту Очир Бургана и дав друг другу золотую клятву» (Сказки и предания ..., 1994: 59). Ср. также: «<...> призвали оба на свое темя Бурган Очира и поклялись друг другу стать друзьями» (там же: 181).

Очень важная для мира тувинских богатырских сказок реалия, представляющая мир географических ориентиров - гора Сюмбер, явная аналогия буддийской горе Сумеру. Из некоторых мифологических рассказов явствует, что эта гора появилась еще до создания мира (Мижит, 2009: 179-180). Гора Сюмбер встречается в текстах весьма часто. Эта гора является местом обитания самих героев, на ней они охотятся, она для них «своя», она дает им все, чтобы поддержать жизнь, что становится ясным из следующих примеров:

«<..> жил тогда простой паренек по имени Эрген-оол. Однажды он поднялся на свою гору Сюмбер, чтобы поохотиться и добыть себе дичи» (Сказки и предания..., 1994: 61);

«Это было время, когда наш истинный муж утолял свою жажду водой золотого и серебряного источников и поднимался на свою большую пеструю гору Сюмбер» (там же: 70);

«Прошло немного времени, и Сулу Балдыр Хаан отправился прямо на запад охотиться на своей горе Сюмбер» (Сказки и предания..., 1994: 135); «Стрелял Гунан Хара Баатыр на своей горе Сюмбер самых красных соболей и самых синих бобров» (там же: 117).

Но есть и такие упоминания о горе, которая выступает своеобразным ориентиром в этом мире для главного героя:

«- Когда ты взберешься на большую и высокую гору Сюмбер, то увидишь тогда перед собой большое море, - сказал он» (там же: 59).

Насыщенность тувинских сказок оронимом-названием горы Сюмбер очень сходно с тем, что калмыцкие топонимисты выявили с названием горы Сумеру, которая для каждой группы и для каждого локуса повествования оказывается организующим центром микрокосма (Хабунова, Гедеева, Убушиева, 2018: 248). 
В текстах тувинских богатырских сказок встречаются и некоторые непонятные реалии, связанные с буддизмом. Рассмотрим фрагмент: «Он кричал два-три дня подряд, и бег ${ }^{1}$ подумал: “Что бы это значило?” - и взял Птичью книгу, есть такая Птичья сутра ${ }^{2}$, взял он ее, заглянул, а там говорилось: “Этому мужчине следует теперь жениться” (Сказки и предания ..., 1994: 155). Следующий пассаж требует исследования: «Сперва лама Баахын Будуяасын произвел очищение и омовение Тайваган Улаана, а потом все отправились на ту битву. А когда они туда отправились, лама Баахын Будуяасын сказал: - Я не из тех, кто пойдет с вами на эту битву: мое дело только воскурять тринадцать жертв Алтаю, - и остался» (там же: 170). Здесь не вполне понятно, мог ли лама по своему статусу приносить жертвы Алтаю.

В фольклоре тувинцев Алтая встречаются легенды, напрямую связанные с рассказами о Будде и его жизни и деятельности. Приведем два таких рассказа. В первом («Легенда о Бурган Башкы и Очирваане») главными персонажами выступают Будда и Ваджрапани:

«Оба, и Бурган Башкы, и Очирваан, хотели, чтобы их считали властителями человечества. И решили они тогда, что властителем над людьми и миром будет тот, в чьей пиале расцветет цветок.

И вот они сидели оба с закрытыми глазами, держа в руках свои пиалы. Очирваан приоткрыл однажды глаза щелочкой и увидал, что в пиале Бурган Башкы распускается цветок лотоса. Он незаметно вынул его и опустил в свою пиалу. Тут Бурган Башкы открыл глаза и сказал:

- Ну, хорошо, ты будешь в этом мире властителем! Но в твоем мире будут войны.

А вот если бы Бурган Башкы стал властителем мира, он бы, так как причина войн всегда волки и покражи, он бы повесил волкам на шею колокольчики, а на голову воров поместил бы огонь, чтобы каждый сразу же мог распознать их. И тогда в его правление мир и люди не знали бы войн» (там же: 284).

Другая легенда «Откуда взялись рыбы» гласит: «Что касается рыб, то Бурган Башкы сказал: - Да станет это пищей детям моим! - отрезал немного мякоти от своих мясистых ляжек и бросил в море» (там же: 285). В этой истории прослеживается мотив жертвования Бодхисаттвой своей плоти ради спасения других живых существ.

Значимый для нашей темы текст - тувинская сказка «Кот-наставник», ее содержание: мыши грызут столбы хурула, лама заводит кота и представляет его мышам как наставника: кот съедает по одной мыши, мыши это замечают, разбегаются и с тех пор избегают кошек (Тувинские народные сказки, 1971: 193).

Буддийские мотивы в тувинском эпосе связаны с эпической топографией и маркировкой эпического пространства названием среднего мира - Замбатиб, которое полностью интегрировано в эпическое повествование: в его границах устраиваются эпические состязания. Исключительно интересен тот факт, что гора Сюмбер (Сумеру) во многих текстах выступает как центр микрокосма повествования и места проживания героя. В единичных текстах проявляются мотивы буддийских повествований. Имена буддийских божеств связаны не с культом, а с изобразительной декоративной практикой. Упоминание Бурган Башкы (Бурхан-бакши, Будды) является исключительным для тувинской фольклорной традиции. Обращает на себя внимание особая насыщенность буддийскими мотивами текстов, записанных Э. Таубе у тувинцев Монголии. Примечательно, что тувинский фольклор становится ценным источником по истории буддийских теонимов и личных имен.

\section{Буддийская космология в топономастиконе бурятского фольклора}

В настоящее время мы располагаем значительным количеством образцов бурятского эпического и сказочного фольклора, в которых проявляются буддийские мотивы. Мы не обращаемся к текстам «Гесера», поскольку они представляют больший интерес для изучения добуддийского компонента верований бурят и воздействия письменного текста на устную традицию (Дугаров, 2005), в частности, тенгрианства, буддийские мотивы занимают в нем менее значимое место (Аюшеева, 2018: 223).

Примечательный фрагмент обнаруживается в бурятском эпосе «Аламжи мэргэн»:

${ }^{1}$ Бег - первоначально обозначение круга лиц из родни мужа, потом - главы родственной группы, позже обобщенно в значении «высокий господин», «князь» (см.: Сказки и предания ..., 1994: 370).

${ }^{2}$ Птичья сутра - текст, целью которого было толкование поведения и полета птиц (см.: там же: 322). 
«Так она говорила-сказывала.

Икры себе разрезав,

Достала священную книгу,

книгу Майдари вынула.

И на столе покатом, серебряном,

Таком, что потянет; его - растянется,

Днем читала она -

При свете солнца читала,

Ночью читала она.

При свете свечей читала.

Так читала она,

Что и есть забывала,

Так читала она,

Что и спать забывала.

Девять суток подряд,

Не отрываясь, читала она

И прочла эти книги

От начала и до конца» (Аламжи Мэргэн, 1991: 167).

Здесь существенно, что эпическая героиня читает сочинение, связанное с бодхисаттвой Майтрейей, будущим преемником будды Шакьямуни.

Локус действия бурятских эпических сказаний - это буддийский центр мироздания, земля Замбатиб:

«Не было у него сил.

Глянул он вниз

Семислойная Замби-земля

Величиной с ладонь, Желтеет,

Великие реки-моря,

Как тонкие иглы» (там же: 205).

Буддийские мотивы в бурятских волшебных сказках встречаются довольно часто и отличаются разнообразием и насыщенностью. В основном это связывается со значительным количеством текстов, включающих буддийские мотивы и, возможно, относительно ранним знакомством бурят с буддизмом (Цыремпилов, 2013; Буддизм в истории и культуре ..., 2014), русские документы об открытии байкальского региона позволяют датировать принятие буддизма бурятами даже началом XVII в. (Бурыкин, 2015). Благодаря этому процессу в культуру бурят вошло множество реалий, связанных с буддизмом.

Начало бурятской сказки «Царь Баян-Хара» напоминает зачин эпических героических сказаний, характерных для тюркской и монгольской эпических традиций и перенятой эвенками - однако здесь, в отличие от якутских и тунгусских эпических текстов здесь присутствует упоминание о горе Сумеру, вошедшей в эпический пейзаж:

«В прежние времена, давние времена, когда земля становилась землей, вода становилась водой, когда гора Сумбэр была еще с бугорок, молочное море было с озерко, когда в табуне рождались только аргамаки, а на радость отцам - только баторы, когда бумага стала тонкой и свиная голова съедобной,- в эти ранние времена жил в западной местности Шана у подошвы трех гор Монгото-ула славный царь Баян-Хара» (Бурятские народные ..., 1990: 145).

Рассмотрим начало бурятской сказки «Харасгай мэргэн»:

«В давние-давние, прошлые прекрасные времена, когда время было чудесным, бумага была тонкой, рыба-великанша была мальком, жили Харасгай Мэргэн и Ату Ногохон. Было у них тридцать три базара и три бурхана, сорок четыре базара и четыре бурхана да светлый дворец, небеса подпирающий, высокий светлый дворец, облаков достигающий. Снизу посмотришь - семь тысяч окон, сверху посмотришь - бесчисленное множество окон, в каждом его углу - (фигурка) бурхана, на каждой стене - изображение хана» (Бурятские волшебные ..., 1993: 117). 
Заметную роль в бурятских сказках играет понятие бурхана - изображения божества, Будды. Стремление приобрести бурхана изображается в сказке «Мэргэн Зоригто»:

«Так в думах да раздумьях Зорикто дошел до города. Зашел он в одну лавку, ничего не купил, заглянул в другую, тоже ничего подходящего не нашел, и подался он на базар. Тут народу видимо-невидимо, всё больше продают, а не покупают. В такой толпе и заблудиться можно; хуже, чем в тайге. Походил, походил Зорикто, потолкался и пошел домой ни с чем. Приходит к отцу с матерью, ложится спать и спит больше суток. Умаялся дорогой, шутка ли, пешком в город сходить. Проснулся Зорикто, отец его спрашивает:

- Чем порадуешь старика, что купил?

- Ничего не купил, - отвечает Зорикто.

- Зачем же ты тогда ноги ломал?

- Искал бурхана, не нашел, вот и пустым пришел домой. Кроме бурхана, мне ничего не надо.

- А знаешь ли ты, что такое бурхан? - спросил отец сына» (Флоренсов, 1927: 7-9).

Как и в фольклоре тувинцев, у бурят в хронотопе сказки встречается гора Сумеру - священная гора буддистов. Например, в бурятской сказке «Старик Молонтой»:

«Что объездил Вселенную, сущую неправду говоришь, трясешь шерстью, не пыли. У подножья горы Сэгтэ Сэмбэр белый изюбрь с острыми (рогами), посередине насквозь простреленный, исходил кровью, пыхтел-лежал. Затем лев за одним человеком гнался. Все это видел?» (Бурятские народные сказки, 2008: 55).

Вот начало сказки «Парень-сирота», вероятно, преобразованной из эпического повествования:

«В давнее время, когда Молочное озеро было еще лужей, гора Сумбэр - кочкой, один сирота-парень у богача пас овец. Тот парень однажды, когда пас овец, сильно устал, утомился» (там же: 164).

Интересные детали присутствуют в сказках из сборника, составленного Б. С. Дугаровым. Например, вот сказка «Ута-Саган Батор»: «После этого (поединка) пятнадцатиголовый мангатхай Ашура-Шара и Ута-Саган-батор обменялись вещими книгами “Шара худар”» (Бурятские народные ... , 1990: 76).

В сказке «Солнечный цветок» именование бурхан входит в обращение к нему: «- Бурханом заклинаю - не делать этого! - взмолилась Наран-Сэсэг» (там же: 143).

В сказке «Царь Баян-Хара» описывается интересный ритуал:

«Услыхали богатырский голос пятьдесят пять тэнгэри, устроили малый суглан на Луне; призвали тысячи белых бурханов, устроили большой суглан на Плеядах. Открыли они священное желтое писание и узнали о том, что не гром гремит, а созданный ими Алтан-Жоло-мэргэн просит у творцов своих коня, доспехи и одежду» (там же: 153).

В сказке «Хитрый придворный» героиня использует в качестве сигнала герою слова буддийской молитвы:

«А Уран Тушэмэл перед девушками похаживает, на красавиц поглядывает. Наконец остановился перед самой улыбчивой и услышал старухин голос: “Ом мани...” Взял он красавицу за руку...» (там же: 166).

Сказка «Газар Поолин, Сын Зээдэлэя» имеет характерное для образцов эпоса и богатырских сказок мифологическое начало, но в ней упоминается и гора Сумбэр, и буддийские божества:

«В те стародавние времена, когда погода стояла благодатная и травы ярко зеленели, когда молочнобелое море лужицей казалось и свиньи отъедались на его берегу, когда исполинская гора Сумбэр была маленькой кочкой, когда развесистое дерево опушки колыхалось молодой порослью и круторогий козел резвился маленьким козленком, в те старопрежние времена жил на свете сын Зээдэлэя Газар Поолин со своей старухой. Была у них дочь Ногоондар - любимица богини Зеленой Тары и сын Сагаандар - любимец богини Белой Тары. Подарили боги брату с сестрой несколько жизней» (там же: 266-267).

В некоторых сказках привлекает внимание даже такие небольшие и малозначимые для сюжета детали, как ритуальная практика, сопровождающая сюжетные события:

«Привез молодец Сагаандар позолоченные подушки Буха-хана и подложил ему под голову, обернул тело парчой и шелком, забил вороного аргамака и похоронил рядом с хозяином. Преломил лук и стрелы, положил их хану на грудь, а над могильным холмом белый молитвенный флажок подвесил» (там же: 282).

«Была у нас единственная дочь-дангина, - отвечает хан. - Отпустили мы ее погулять вместе с двумя сановника. И с тех пор их нет, как в воду канули. Мы не знаем, куда делась наша дочь, но думаем, что случилось самое худшее, поэтому и пригласили почтенных лам на поминальную молитву. - После этих слов хан опустил голову в большой печали, а ханша зарыдала (там же: 310-311). 
Буддийский топономастикон, или ономастическая картина мира встречается в бурятских фольклорных текстах, примерно в том же составе, в каком она наблюдается в фольклоре калмыков и тувинцев. Это выражено прежде всего в упоминании Замбатиба и горы Сумеру в тех формах, в каких они характерны для традиции. Из имен божеств в бурятских фольклорных тектах встречаются Бодисаттва Майтрейя и название сутры «Шара худар». Стоит отметить, что в бурятских фольклорных текстах встречается множество предметов, связанных с буддийской культурой, которые наполняют повествование характерными для культуры деталями.

\section{Заключение}

Буддийские элементы, которые можно обнаружить в сказках и эпосе калмыков, героических сказаниях и сказках тувинцев и в сказках и эпосе бурят в целом относительно немногочисленны, и, как можно судить, появились в фольклорных традициях разных народов независимо друг от друга. Часть таких элементов - объекты, формирующие пейзаж Среднего мира в буддийской космологии как научного сегмента и как сферы, где живут люди. Названия этих объектов - такие как Замбатиб или гора Сумеру выступают в роли дополнительного элемента фольклорного пейзажа, что особенно заметно в образцах эпоса, где гора Сумеру вписывается в архаический мифологический пейзаж, одновременно с этим у каждой группы, о которой повествуют фольклорные произведения, оказывается своя гора Сумеру - это четко видно в фольклоре тувинцев и сохранилось в представлениях о географическом мире у калмыков. В отдельных случаях в текстах появляются имена буддийских божеств - здесь они имеют разные функции от божеств как действующих лиц, как у тувинцев, до обозначений изображений божеств в окружающем материальном мире. Будда в фольклоре именуется Бурхан или Бурхан-бакши (Бурган Башкы).

Самое интересное в исследовании - удалось установить, что в том, что буддийские мотивы в традициях трех народов, исповедующих буддизм, в основном связаны с социальным миром и предметным миром. Примером первого являются образы лам, примером второго - изображения божеств и названия священных книг. Эти детали текста дополняют традиционную фольклорную картину мира и создают как бы декорации для развертывания содержания текста, позволяя изучать характер отражения реального мира в устной словесности.

Фрагментированность и неоднородное распределение упоминаний Замбатиба, а также разные формы его наименования, как и различающийся набор теонимов, наилучшим образом представленных у тувинцев, указывают на неоднородность и вероятную гетерогенность географической картины мира в эпосах тувинцев, бурят и калмыков.

Примечательно, что в фольклорное повествование проникают отдельные названия буддийских сочинений и тексты молитв. Буддийские ритуалы вписываются в фольклорное повествование как одна из сфер традиционной практики народов, описание которых входит в эпос вместе с разнообразными деталями. Это насыщение фольклора ставит под сомнение гипотезу А. И. Зайцева, согласно которой волшебные сказки появляются в обществе со сложной социальной организацией, в котором функционирует письменность (Зайцев, 1984). Любопытно, что у тувинцев появляются фольклорные версии книжных повествований (Донгак, 2004), что видно на примере рассказа о коте. Пространственновременная картина в эпических формах фольклора привлекает внимание исследователей в поисках возможных вариантов ее формализации в связи с точными науками (Сатанар, 2020).

Дальнейшие исследования в области распространения литературно-книжной традиции, представляющей буддийское наследие, и его отражения в фольклоре отдельных этносов, а также опыты сопоставления легендарной и исторической топонимии религиозных и устных фольклорных текстов (см. например: Халтуева, 2009) представляются весьма важными как для изучения процессов развития фольклора, так и для характера процессов рецепции буддизма, изучения культурообразующей роли буддизма для народов Центральной Азии, характера эволюции культурных и конфессиональных компонентов буддизма при его распространении на север. Весьма значимые в теории и практике результаты обещает исследование характера направлений лексических заимствований и заимствований сюжетов и мотивов в фольклоре и литературе. Исследования в названных областях могут привести к интересным результатам и выводам. 


\section{СПИСОК ЛИТЕРАТУРЫ}

Аламжи мэргэн. Бурятский героический эпос (1991) / отв. ред. А. Б. Соктоев. Новосибирск : Наука, СО. 312 с.

Аюшеева, Э. Б. (2018) Особенности образа ламы в бурятской Гесериаде // Филологические науки. Вопросы теории и практики. № 12 (90). Ч. 2. С. 222-225.

Бадгаев, Н. Б. (2014) Религиозная лексика в калмыцком героическом эпосе «Джангар» // Вестник Калмыцкого института гуманитарных исследований РАН. 2014. № 4. С. 113-118.

Бакаева, Э.П. (2004) О буддийских элементах в эпосе «Джангар» // «Джангар» и проблемы эпического творчества: мат-лы. межд. науч. конф. / отв. ред. Н. Ц. Биткеев, Э. Б. Овалов. Элиста : АПП «Джангар». 602 с. С. 358-363.

Бакаева, Э. П. (2008а) Проблема прародины этнических предков калмыков (по материалам добуддийских верований) // Вестник Прикаспия: археология, история, этнология. № 1. С. 204-211.

Бакаева, Э. П. (2008b) Калмыцкий буддизм: история и современность // Религия в истории и культуре монголоязычных народов России / сост. и отв. ред. Н. Л. Жуковская. М. : Восточная литература. 320 с. С. 161-200.

Биткеев, Н. Ц. (2011) «Джангар» и джангароведение // «Джангар» и эпические традиции народов Евразии: проблемы исследования и сохранения. Материалы Международной научной конференции (г. Элиста, 20-23 сентября 2011 г.) / отв. ред Н. Г. Очирова. Элиста : КИГИ РАН. 173 с. С. 18-22.

Богда Чаңгар хан : Тувинская сказка-эпос (1973) / сказ. Б. У. Балбыр; зап., подстр. пер. Д. С. Куулар; предисл. А. Ш. Кичикова // Уч. зап. Калмыцкого Научно-исследовательского Института языка, литературы и истории. Элиста : б. и. Вып. ХІ. С. 118-127.

Борджанова, Т. Г. (2000) Ойратский героический эпос и буддизм // Буддийская культура и мировая цивилизация на пороге III тысячелетия: Материалы конф. / под ред. Д. А. Гущина, В. Н. Илюмжинова, Ю. Н. Солонина СПб. ; Элиста : Изд-во СПбГУ. 212 с. С. 116-117.

Буддизм в истории и культуре бурят (2014): коллективная монография / под ред. И. Р. Гарри. Улан-Удэ: БуряадМонгол Ном. 417 с.

Бурыкин, А. А. (2003) Почему в Малодербетовской версии «Джангара» ханская ставка похожа на буддийскую ступу? (еще раз к проблеме мотивов изобразительного искусства в «Джангаре») // Буддийская культура и мировая цивилизация. Материалы третьей российской научной конференции (22-26 сентября 2003 г.) / под ред.: К. А. Наднеева, О. В. Усалко. Элиста : Изд-во КГУ. 214 с. С. 69-72.

Бурыкин, А. А. (2013) Имена собственные как исторический источник. По материалам русских документов об открытии Сибири и Дальнего Востока XVII-XIX вв. СПб. : Петербургское востоковедение. 534 с.

Бурыкин, А. А. (2015) Из истории лексики, связанной с буддизмом, в русском литературном языке XVII - начала XXI веков (позиции в буддийской церковной иерархии) // Буддийская культура: история, источниковедение, языкознание и искусство: буддизм и современный мир: материалы конференции. Улан-Удэ - Нарын-Ацагат, 13-16 июля 2014 г. / отв. ред. А. О. Бороноев. СПб. : Гиперион. 430 с. С. 239-248.

Бурыкин, А. А., Басангова, Т. Г. (2014) Типология калмыцкого фольклора / отв. ред. Д. Н. Музраева. Элиста : ЗАОр «НПП „Джангар“». 212 с.

Бурятские волшебные сказки (1993) / отв. ред. А. Б. Соктоев. Новосибирск : ВО «Наука», Сибирская издательская фирма. 341 с.

Бурятские народные сказки (1990) / сост. Б. С. Дугаров. М. : Современник. 389 с.

Бурятские народные сказки. Волшебные. Бытовые (2008) / сост. С. С. Бардаханова, С. Д. Гымпилова; отв. ред. Л. С. Дампилова. Улан-Удэ : Изд-во БНЦ СО РАН. 187 с.

Ванчикова, Ц. П., Чимитдоржин, Д. Г. (2006) История буддизма в Бурятии: 1945-2000 гг. Улан-Удэ : Изд-во БНЦ СО РАН. 147 с.

Гедеева, Д. Б. (2013) Буддийская лексика в калмыцких микротопонимах // Бааза-Багши и его духовное наследие / отв. ред. Е. Э. Хабунова. Элиста : ЗАОр «НПП „Джангар“». 160 с. С. 52-54.

Гребнев, Л. В. (1960) Тувинский героический эпос: (Опыт историко-этнографического анализа). М. : Издательство «Восточная литература». 147 с.

Дарбакова, В. П. (1997) Эпос «Джангар» - венец буддийского Ренессанса // Проблемы современного джангароведения: материалы респ. науч.-практ. конф., посв. 75-летию профессора А. Ш. Кичикова : в 2-х кн. / отв. ред. А. В. Бадмаев. Элиста : Изд-во КГУ. Кн. 2.85 с. С. 63-64.

Джангар (1988): Калмыцкий народный героический эпос. Эпический репертуар Мукебюна Басангова / пер. с калм., предисл., коммент, и словарь Н. Ц. Биткеева. Элиста : Калм. кн. изд-во. 158 с. 
Джангар (1990): Калмыцкий героический эпос / сост., подг. текстов, коммент. и словарь Н. Ц. Биткеева, Э. Б. Овалова; пер. с калм. Н. Ц. Биткеева, Э. Б. Овалова, Ц. К. Корсункиева и др. М. : Наука, ГРВЛ. 475 с.

Джангар (1999): Малодербетская версия = Жаңһр / сводный текст, пер., вступ. ст., коммент., словарь А. Ш. Кичикова; отв. ред. А. В. Бадмаев. Элиста : КГУ. 272 с.

Донгак, А. С. (2004) Сюжеты и мотивы «обрамленных повестей» в тувинской сказочной традиции : автореф. дис. ... канд. филол.наук. Улан-Удэ. 20 с.

Донгак, А. С. (2018) Легенды и устные рассказы об истории распространения буддизма в тувинском фольклоре // Oriental Studies. № 1. С. 113-120.

Дугаров, Б. С. (2005) Сакральный мир бурятской Гэсэриады: Небесный пантеон и генезис героя : автореф дисс.... докт. филол. наук. Улан-Удэ. 45 с.

Дугаров, Б. С. (2017) Феномен книги в тюрко-монгольском эпосе: буддийское влияние и алтайско-бурятские параллели // Ученые записки (Алтайская государственная академия культуры и искусств). № 1. С. 82-88.

Дугаров, Б. С., Николаева, Н. Н. (2015) Бурятский героический эпос как этнокультурный феномен в контексте нематериального культурного наследия бурят // Вестник Бурятского государственного университета. Язык. Литература. Культура. Вып. 10 (1). Филология. С. 271-275.

Зайцев, А. И. (1984) К вопросу о происхождении волшебной сказки // Фольклор и этнография. У этнографических истоков фольклорных сюжетов и образов / под ред. Б. Н. Путилова. Л. : Наука, ЛО. 254 с. С. 69-77.

История буддизма в СССР и Российской Федерации в 1985-1999 гг. (2010) / под. общ. ред. Н. Г. Очировой. М. : Фонд современной истории. 392 с.

Калмыцкие богатырские сказки (2017) / подготовка текстов, переложение калмыцких текстов, перевод, примечания, комментарии, указатели, словарь Б. Б. Манджиевой, Т. А. Михалевой, Ц. Б. Селеевой; отв. ред. А. А. Бурыкин, Г. Ц. Пюрбеев, Е. Н. Кузьмина. Элиста : КалмНЦ РАН. 561 с.

Ковалевский, О. М. (1837) Буддийская космология. Казань : Университетская типография. 167 с.

Куулар, Д. С. (2004) Тувинская версия «Джангара» // «Джангар» и проблемы эпического творчества: мат-лы межд. науч. конф. / отв. ред. П. Ц. Биткеев, Э. Б. Овалов. Элиста : АПП «Джангар». 602 с. С. 143-148.

Лиджиев, А. Б. (2010) Отражение буддизма в ойрат-калмыцких топонимах // Мир буддийской культуры: наследие и современность : материалы III Международного симпозиума, 3-5 ноября 2010 г., Чита - Агинское / отв. ред. М. И. Гомбоева. Чита : Экспресс-издательство. 323 с. С. 182-187.

Манджиева, Б. Б. (2016) К проблеме составления тома «Калмыцкие богатырские сказки» в Своде калмыцкого фольклора // Вестник Тувинского государственного университета. Педагогические науки. № 4. С. 74-80.

Мижит, Л. С. (2009) «Тройственные образы в мифологии и фольклоре тувинцев [Электронный ресурс] // Новые исследования Тувы, № 4. URL: https://nit.tuva.asia/nit/article/view/601 (дата обращения: 27.07.2020).

Мижит, Э. Б. (2010) Тувинская традиционная космология в героическом эпосе [Электронный ресурс] // Новые исследования Тувы. № 1. С. 149-172. URL: https://nit.tuva.asia/nit/article/view/570 (дата обращения: 03.03.2020).

Мифы, легенды, предания тувинцев (2010) / отв. ред. В. В. Илларионов. Новосибирск : Наука. 372 с.

Монгуш, М. В. (2001) История буддизма в Туве (вторая половина VI - конец XX в.). Новосибирск : Наука. 200 с.

Монгуш, М. В. (2008) Религия в истории и современной культуре тувинцев // Религия в истории и культуре монголоязычных народов России / сост. и отв. ред. Н. Л. Жуковская. М. : Восточная литература. 318 с. С. $215-241$.

Монраев, М. У. (2012) Калмыцкие личные имена (семантика). 3-е изд. Элиста : АУ РК «Издат. дом „Гэрэл“». 255 с.

Музраева, Д. Н. (2014) Бурхан. К истории одного тюрко-монгольского слова в русском языке // Монголоведение. № 7. С. 28-42.

Музраева, Д. Н. (2016) Буддийские и добуддийские мотивы в калмыцкой сказке «72 небылицы» // «Джангар» и эпические традиции тюрко-монгольских народов: проблемы сохранения и исследования. Материалы III Международной научной конференции / ред: Т. Г. Басангова, Б. Б. Манджиева, отв. ред. В. В. Куканова. Элиста : КИГИ PAH. 324 с. С. $166-169$.

Овшинов, А. Н. (2020) Героический эпос «Джангар» - философия жизни предков калмыков // Гуманитарий Юга России. Том 9. № 2. С. 234-248. DOI: https://doi.org/10.18522/2227-8656.2020.2.17

Ондар, Б. К. (2007) Топонимический словарь Тувы. 2-е изд. Кызыл : Тувинское книжное издательство. 551 с.

Ондар, М. В. (2016) База данных текстов тувинского героического эпоса: первый этап [Электронный ресурс] // Новые исследования Тувы. № 4. С. 66-76. URL: https://nit.tuva.asia/nit/article/view/616 (дата обращения: 03.03.2020).

Орус-оол, С. М. (2001) Тувинские героические сказания (Текстология, поэтика, стиль) / отв. ред. В. М. Гацак. М. : МАКС Пресс. 428 с. 
Орус-оол, С. М. (2011) О переводах тувинского героического эпоса на русский язык // Орус-оол С. М. Избранные научные труды / сост. М. Б. Кунга. Абакан : ООО «Журналист». 296 с. С. 55-68.

Орус-оол, С. М. (2018) Тенгрианство в тувинском фольклоре [Электронный ресурс] // Международный Фонд исследования Тенгри. URL: http://tengrifund.ru/tengrianstvo-v-tuvinskom-folklore.html (дата обращения: 03.03.2020).

Очир-Горяев, В. Э. (1978) Топонимика «Джангара» (к постановке вопроса) // «Джангар» и проблемы эпического творчества тюрко-монгольских народов: тез. докл. и сообщ. всесоюзн. науч. конф. / ред. П. Ц. Биткеев, Э. Б. Овалов, Б. Б. Оконов. Элиста : КНИИЯЛИ. 144 с. С. 130-132.

Поляев, В. О. (1978) Тибетско-санскритские лексические элементы в языке «Джангара» // «Джангар» и проблемы эпического творчества тюрко- монгольских народов: тез. докл. и сообщ. всесоюзн. науч. конф. / ред. П. Ц. Биткеев, Э. Б. Овалов, Б. Б. Оконов. Элиста : КНИИЯЛИ. 144 с. С. $98-100$.

Поппе, Н. Н. (1941) Об отношении бурят-монгольского Гэсэра к монгольской книжной версии // Записки ГИялИ. Улан-Удэ : Бурят-Монгольский гос. НИИ языка, литературы и истории. Вып. 5-6. С. 7-19.

Сатанар, М. Т. (2020) Экспликация некоторых кодов мифологической системы якутского эпоса олонхо (к постановке вопроса о фольклорном времени и пространстве) // Научный диалог. № 6. C. 302-319. DOI: https://doi. org/10.24224/2227-1295-2020-6-302-319

Селеева, Ц. Б. (2019) Сюжетно-типологические особенности сказания «Богдо Чаңгар хан» в традиции тувинцев и эпоса «Джангар» в национальных версиях калмыков России и ойратов Синьцзяна // Новые исследования Тувы. № 4. С. 133-139. DOI: https://www.doi.org/10.25178/nit.2019.4.11

Сказки и предания алтайских тувинцев (1994) / собраны Э. Таубе; авториз. перевод с нем. Б. Е. Чистовой. М. : Восточная литература. 380 с.

Справочник личных имен народов РСФСР (1979) / отв. ред. А. В. Суперанская. 2-е изд. М. : Русский язык. 656 с.

Торбоков, А. В. (2017) Буддийская лексика алтайского героического эпоса // Актуальные проблемы алтайской драматургии в XXI веке:К 120-летию Павла Кучияка. Материалы региональной научно-практической конференции / под ред. М. С. Дединой. Горно-Алтайск : Горно-Алтайский государственный университет. 291 с. С. 267-275.

Тувинские героические сказания: «Хунан-Кара», «Боктуг-Кириш», «Бора-Шэлей» (1997) / сост. С. М. Орус-оол. Новосибирск : Наука. СО. 584 с.

Тувинские народные сказки (1971) / пер., сост. и прим. М. Ватагина, предисловие Д. С. Куулара. М. : Главная редакция восточной литературы издательства «Наука». 208 с.

Тувинские народные сказки (1994) / ред. З. Б. Самдан. Новосибирск : Наука. 460 с.

Уланов, А. И. (1957) К характеристике героического эпоса бурят. Улан-Удэ : Бурят-Монгол. кн. изд-во. 171 с.

Уланов, А. И. (1963) Бурятский героический эпос. Улан-Удэ : Бурят. кн. изд-во. 220 с.

Флоренсов, В. Н. (1927) Мэргэн Зоригто Монголо-бурятская сказка о Мэргэн-Зорикто. Иркутск : Власть труда. $16 \mathrm{c}$.

Хабунова, Е. Э., Гедеева, Д. Б., Убушиева, Б. Э. (2018) Топонимы в фольклорном контексте калмыков // Новые исследования Тувы. № 3. С. 242-258. DOI: https://doi.org/10.25178/nit.2018.3.16

Хабунова, Е. Э., Дампилова, Л. С., Кунгаа, М. Б. Аюушжавийин, А. (2019) Тувинское сказание «Богда Чангар хан» и его константные сегменты в ойратской и калмыцкой версиях героического эпоса «Джангар» // Новые исследования Тувы. № 4. С. 109-118. DOI: https://www.doi.org/10.25178/nit.2019.4.9

Халтуева, Г. О. (2009) Топонимический лексикон «Сокровенного сказания монголов» и «Кодзики»: общее и частное : автореф. дис. ... канд. филол. наук. Улан-Удэ. 25 с.

Хангалов, М. Н. (2004) Собрание сочинений : в 3 т. / под ред. Г. Н. Румянцева. Улан-Удэ : ОАО «Республиканская типография». Т. III. 312 с.

Хертек, Л. К. (2015) К вопросу о лингвистическом анализе эпических текстов // Филологические науки. Вопросы теории и практики. № 12 (54). Ч. І. С. 188-190.

Хомушку, О. М. (2006) Религиозный синкретизм у народов Саяно-Алтая : автореф. ... дис. докт. филос. наук. M. 53 c.

Цыбенова, Б. Б. (2000) Общности и различия бурятского эпоса «Гэсэр» и калмыцкого эпоса «Джангар» : дисс ... канд. филол. наук. Улан-Удэ. 162 с.

Цыремпилов, Н. В. (2013) Буддизм и империя: бурятская буддийская община в России (XVIII - нач. XX в.) / отв. ред. Б. В. Базаров; Учреждение Рос. академии наук, Ин-т монголоведения, буддологии и тибетологии Сиб. отд-ния РАН. Улан-Удэ : ИМБТ СО РАН. 338 с. 
Чингэлтэй, Б. (2004) Влияние буддийской литературы на эпос «Джангар» // «Джангар» и проблемы эпического творчества: мат-лы межд. науч. конф. / отв. ред. П. Ц. Биткеев, Э. Б. Овалов. Элиста : АПП «Джангар». 602 с. С. 318-324.

Шаракшинова, Н. О. (1987) Героико-эпическая поэзия бурят. Иркутск : Изд-во Иркутского университета. 304 с.

Шойнжонов, Б. Б. (2008) Отражение религиозно-культовых представлений в бурятском фольклоре : автореф. дис. ... канд. филол. наук. Улан-Удэ. 27 с.

Дата поступления: 10.05.2020 г.

\section{REFERENCES}

Alamzhi mehrgehn. Buryatskii geroicheskii epos [Alamzhi Mergen. Buryat heroic epic] (1991). Ed. by A. B. Soktoev. Novosibirsk, Nauka. Sib. Branch Publishers. 312 p. (In Russ.).

Aiusheeva, E. B (2018) Osobennosti obraza lamy v Buryatskoii Geseriade [Specific features of the lama in the Buryat version of the Geseriada]. Philological sciences. Questions of theory and practice, no. 12(90), part 2, pp. 222-225. (In Russ.).

Badgaev, N. B. (2014) Religioznaia leksika v kalmytskom geroicheskom epose "Dzhangar" [Lexics of religion in Kalmyk heroic epic "Dzhangar”]. Vestnik Kalmyckogo instituta gumanitarnykh issledovanii RAN, no. 4, pp. 113-118. (In Russ.).

Bakaeva, E. P. (2004) O buddiiskikh ehlementakh v epose "Dzhangar" [On the Buddhist elements in the epic “Dzhangar"]. In: "Dzhangar" i problemy ehpicheskogo tvorchestva ["Dzhangar" and the problems of epic creativity]: proceedings of an international conference]. Ed. by N. Ts. Bitkeev and E. B. Ovalov. Elista, "Dzhangar” Publishers. 602 p. Pp. 358-363. (In Russ.).

Bakaeva, E. P. (2008a) Problema prarodiny etnicheskikh predkov kalmykov (po materialam dobuddiiskih verovanii) [The problem of the ancestral homeland of the ethnic ancestors of the Kalmyks: from pre-Buddhist belief systems]. Caspian Bulletin: archeology, history, ethnology, no. 1, pp. 204-211 (In Russ.).

Bakaeva, E. P. (2008b) Kalmytskii buddizm: istoriia i sovremennost' [Kalmyk Buddhism: History and Modernity]. In: Religiia v istorii i kul'ture mongoloiazychnykh narodov Rossii [Religion in the history and culture of Mongolian-speaking peoples of Russia]. Comp. and ed. by N. L. Zhukovskaia. Moscow, Oriental literature Publ. 320 p. Pp. 161-200. (In Russ.).

Bitkeev, N. C. (2011) “Dzhangar” i dzhangarovedenie ["Dzhangar” and “Dzhangar” studies]. In: “Dzhangar” i epicheskie traditsii narodov Evrazii: problemy issledovaniia i sokhraneniia ["Dzhangar" and the epic traditions of the peoples of Eurasia] : problems of research and preservation. Proceedings of the International Scientific Conference. Ed. by N. G. Ochirova. Elista, KIHR RAS. 172 p. Pp. 18-22. (In Russ.).

Bogda Changar khan: Tuvinskaia skazka-epos [Bogda Changar the khan: the Tuva epic fairy tale] (1973). B. U. Balbyr (narrator); record, transl. by D. S. Kuular; Preface by A. Sh. Kichikov. In: Uchenye zapiski, Kalmyckogo Nauchno-issledovatel'skogo Instituta yazyka, literatury i istorii. Elista. Vol. XI. Pp. 118-127. (In Russ.).

Bordzhanova, T. G. (2000) Oiratskii geroicheskii epos i buddizm [Oirat heroic epic and Buddhism]. In: Buddiiskaia kul'tura i mirovaia civilizaciia na poroge III tysjacheletiia [Buddhist culture and world civilization on the threshold of the $3^{\text {rd }}$ millennium]: Materials of the conf. Ed. by D. A. Gushhin, V. N. Iljumzhinov and Yu. N. Solonin. St. Petersburg, Elista, SPbSU Publishers. 212 p. Pp. 116-117. (In Russ.).

Buddizm v istorii i kul'ture Buryat [Buddhism in the history and culture of Buryats] (2014). Ed. by I. R. Garri. Ulan-Ude, Buryaad-Mongol Nom. 417 p. (In Russ.).

Burykin, A. A. (2003) Pochemu v Maloderbetovskoy versii "Dzhangara" khanskaya stavka pokhozha na buddiyskuyu stupu? (yeshche raz k probleme motivov izobrazitel'nogo iskusstva v "Dzhangare") [Why is the Khan's residence in the Maloderbetovsky version of "Dzhangar" similar to a Buddhist stupa?: a new take on the problem of motives of art in "Dzhangar")]. In: Buddiyskaya kul'tura i mirovaya tsivilizatsiya [Buddhist culture and world civilization]. Materials of the third All-Russian conference. Ed. by K. A. Nadneev and O. V. Usalko. Elista, KSU Publ. 216 p. Pp. 69-72. (In Russ.).

Burykin, A. A. (2013) Imena sobstvennye kak istoricheskii istochnik. Po materialam russkih dokumentov ob otkrytii Sibiri $i$ Dal'nego Vostoka XVII-XIX vv. [Proper names as a historical source: from the Russian documents on the discovery of Siberia and the Far East, 17th - 19th centuries]. St. Petersburg, Petersburg Oriental studies Publishers. 534 p. (In Russ.).

Burykin, A.A. (2015) Iz istorii leksiki, sviazannoii s buddizmom, v russkom literaturnom yazyke XVII - nachala XXI vekov (pozitsii v buddiiskoii tserkovnoii ierarkhii) [From the history of Buddhism-related lexics in Russian literary language of $17^{\text {th }}$ - early 21 st centuries]. In: Buddiiskaia kul'tura: istoriia, istochnikovedenie, jazykoznanie i iskusstvo [Buddhist culture: history, source studies, linguistics and art: Buddhism and the modern world] : conference proceedings. Ulan-Ude-NarynAtsagat, July 13-16, 2014 / Ed. by A. O. Boronoev. St Petersburg, Giperion. 430 p. Pp. 239-248. (In Russ.). 
Burykin, A. A. and Basangova, T. G. (2014) Tipologiia kalmytskogo fol'klora [Typology of Kalmyk folklore]. Ed. by D. N. Muzraeva. Elista, Dzhangar Publishers. 212 p. (In Russ.).

Buryatskie volshebnye skazki [Buryat magic tales] (1993). Ed by A. B. Soktoev. Novosibirsk, Nauka, Siberian publishing firm. 341 p. (In Russ.).

Buryatskie narodnye skazki [Buryat folk tales] (1990). Comp. by B. S. Dugarov. Moscow, Sovremennik Publishers. 389 p. (In Russ.).

Buryatskie narodnye skazki. Volshebnye. Bytovye skazki [Buryat folk tales. Magic tales. Household tales] (2008). Comp. by S. S. Bardakhanova and S. D. Gympilova; ed. by L. S. Dampilova. Ulan-Ude, BNC of SB RAS Publishers. 187 p. (In Russ.).

Vanchikova, C. P. and Chimitdorzhin, D. G. (2006) Istoriia buddizma v Buryatii: 1945-2000 gg [The history of Buddhism in Buryatia: 1945-2000]. Ulan-Ude, BSC of SB of the RAS Publishers. 147 p. (In Russ.)

Gedeeva, D. B. (2013) Buddiiskaia leksika v kalmyckikh mikrotoponimakh [Buddhist vocabulary in Kalmyk microtoponymics]. In: Baaza-Bagshi i ego dukhovnoe nasledie [Baaza-Bagshi and his spiritual heritage]. Ed. by E. Er. Khabunova. Elista, Dzhangar Publishers. 160 p. Pp. 52-54. (In Russ.).

Grebnev, L. V. (1960) Tuvinskii geroicheskii epos (opyt istoriko-etnograficheskogo analiza) [Tuvan heroic epic: a historical and ethnographic analysis]. Moscow, Oriental literature Publ. 145 p. (In Russ.).

Darbakova, V. P. (1997) Epos “Dzhangar” - venets buddiiskogo Renessansa [Epic “Dzhangar”, the pinnacle of the Buddhist Renaissance]. In: Problemy sovremennogo dzhangarovedeniia [Problems of contemporary Dzhangar studies]: Proceedings of a conference dedicated to the 75th anniversary of professor A. Sh. Kichikov: in 2 books. Ed. by A. V. Badmaev. Elista, KSU Publishers. Book 2. 85 p. Pp. 63-64. (In Russ.).

Dzhangar. Kalmytskii narodnyi geroicheskii epos. Epicheskii repertuar Mukebyuna Basangova [Dzhangar: the Kalmyk national heroic epic. Epic in the repertoire of Mukebyun Basangov] (1988). Transl. from Kalm., Preface, comment., and Glossary' by N. Ts. Bitkeev. Elista, Kalmyk Book Publishers. 158 p. (In Russ.).

Dzhangar. Kalmytskii geroicheskii epos ["Dzhangar": the Kalmyk heroic epic] (1990). Comp., prep. texts, comments and vocabulary by N. Ts. Bitkeeva, E. B. Ovalova; transl. from Kalm. by N. Ts. Bitkeeva, E. B. Ovalova, S. K. Karankawa et al. Moscow, Nauka, Oriental literature Publ. 475 p. (In Kalmyk and Russ.).

Dzhangar. Maloderbetskaia versiia = Zhanggar [Jangar: Maloderbetsky version = Dzhangar] (1999). Consolidated text, transl., introduction, comments, dictionary by A. Sh. Kichikova, ed. by A. V. Badmaev. Elista, KSU Publishers. 272 p. (In Kalmyk and Russ.).

Dongak, A. S. (2004) Siuzhety i motivy "obramlennykh povesteii" v tuvinskoii skazochnoii tradicii [Plots and motives of "framed stories" in Tuvan folk tale tradition]. Abstract of Diss.... Candidate of Philology. Ulan-Ude. 20 p. (In Russ.).

Dongak, A. S. (2018) Legendy i ustnye rasskazy ob istorii rasprostraneniia buddizma v tuvinskom fol'klore [History of Buddhism's Dissemination in Tuvan Folklore: Legends and Oral Narratives]. Oriental Studies, no. 1, pp. 113-120. (In Russ.).

Dugarov, B. S. (2005) Sakral'nyii mir Buryatskoii Geseriady: Nebesnyii panteon i genezis geroia [The sacral world of Buryat Geseriada. Sky pantheon and the origin of the hero]. Abstract of Diss.... Doctor of Philology. Ulan-Ude. 45 p. (In Russ.).

Dugarov, B. S. (2017) Fenomen knigi v tyurko-mongol'skom epose: buddiiskoe vliianie i altaiisko-Buryatskie paralleli [The phenomenon of the book in Turkic-Mongolian epic: Buddhist influence and Buryat-Altaic parallels]. Uchenye zapiski (Altaiiskaia gosudarstvennaia akademiia kul'tury i iskusstv), no. 1, pp. 82-88. (In Russ.).

Dugarov B. S. and Nikolaeva N. N. (2015) Buryatskii geroicheskii epos kak ehtnokul'turnyii fenomen v kontekste nematerial'nogo kul'turnogo naslediia Buryat [Buryat heroic epic as an ethnic cultural phenomenon in the context of non-material cultural heritage of Buryats]. Bulletin of the Buryat State University. Tongue. Literature. Culture, no. 10 (1), Filologiia, pp. 271-275. (In Russ.).

Zaitsev, A. I. (1984) K voprosu o proiskhozhdenii volshebnoii skazki [On the origin of magic tale]. In: Fol'klor $i$ ehtnografiia. U ehtnograficheskikh istokov fol'klornykh sjuzhetov i obrazov [Folklore and Ethnography. At the ethnographic origins of folklore plots and images]. Ed. by B. N. Putilov. Leningrad, Nauka, Leningrad branch Publishers. 254 p. Pp. 69-77. (In Russ.).

Istoriia buddizma v SSSR i Rossiiskoi Federacii v 1985-1999 gg. [The history of Buddhism in the USSR and the Russian Federation in 1985-1999] (2010). N. G. Ochirova (ed.). Moscow, Fond sovremennoi istorii Publishers. 392 p. (In Russ.).

Kalmytskie bogatyrskie skazki [The Kalmyk heroic tales] (2017). Preparation of texts, retelling of Kalmyk texts, translation, notes, comments, indexes, and vocabulary by B. B. Mandzhieva, T. A. Mikhaleva and T. S. Seleeva. Elista, KalmSC of the RAS Publ. 561 p. (In Russ.). 
Kovalevskii, O. M. (1837) Buddiiskaia kosmologiia [Buddhist cosmology]. Kazan, University printing house Publishers. 167 p. (In Russ.).

Kuular, D. S. (2004) Tuvinskaia versiia “Dzhangara” [The Tuvan version of “Dzhangar”]. In: “Dzhangar” i problemy epicheskogo tvorchestva ["Dzhangar" and problems of epic creativity]: Proceedings of an international conference. Ed. by N. Ts. Bitkeeva and E. B. Ovalov. Elista, Dzhangar Publishers. 602 p. Pp. 143-148 (In Russ.).

Lidzhiev, A. B. (2010) Otrazhenie buddizma v oiirat-kalmyckikh toponimakh [Reflection of Buddhism in Kalmyk toponims]. In: Mir buddiiskoii kul'tury: nasledie i sovremennost' [The world of Buddhist culture: heritage and modernity]: proceedings of the $3^{\text {rd }}$ International symposium. Chita, Ehkspress Publ. 323 p. Pp. 182-187. (In Russ.).

Mandzhieva, B. B. (2016) K probleme sostavleniia toma "Kalmyckie bogatyrskie skazki” v Svode kalmyckogo fol'klora [On compiling the volume "Kalmyk heroic tales" in the Collection of Kalmyk folklore]. Bulletin of the Tuva State university. Pedagogical Sciences, no. 4, pp. 74-80. (In Russ.).

Mizhit, L. S. (2009) Troiistvennye obrazy v mifologii i fol'klore tuvincev [Triple images in mythology and folklore of Tuvans]. New Research of Tuva, no. 4 [online] Available at: https://nit.tuva.asia/nit/article/view/601 (access date: 27.04.2020).

Mizhit, Eh. B. (2010) Tuvinskaia traditsionnaia kosmologiia v geroicheskom epose [Tuvan traditional cosmology in the heroic epic]. New Research of Tuva, no. 1, pp. 149-172 [online] Available at: https://nit.tuva.asia/nit/article/view/570 (access date: 27.04.2020). (In Russ.).

Mify, legendy, predaniya tuvintsev [Myths, legends and tales of the Tuvans] (2010). Ed. by V. V. Illarionov. Novosibirsk, Nauka. 372 p. (In Russ.).

Mongush, M. V. (2001) Istoriya buddizma v Tuve (vtoraya polovina VI - konets XX v.) [The History of Buddhism in Tuva (latter half of the $6^{\text {th }}-$ late $20^{\text {th }} c c$. )]. Novosibirsk, Nauka. 200 p. (In Russ.).

Mongush, M. V. (2008) Religiia v istorii i sovremennoii kul'ture tuvintsev [Religion in the history and modern culture of Tuvans]. In: Religiia v istorii i kul'ture mongoloiazychnykh narodov Rossii [Religion in the history and culture of Mongolianspeaking peoples of Russia]. Comp. and ed. by N. L. Zhukovskaia. Moscow, Eastern literature Publ. 318 p. Pp. 215-241. (In Russ.).

Monraev, M. U. (2012) Kalmyckie lichnye imena (semantika) [Kalmyk personal mnames (semantics)]. $3^{\text {rd }}$ ed. Elista, Gerel Publ. 255 p.

Muzraeva, D. N. (2014) Burkhan. K istorii odnogo tyurko-mongol'skogo slova v russkom yazyke [Burkhan. On the history of a Turkic-Mongolian word in Russian]. Mongolian studies, no. 7, pp. 28-42. (In Russ.).

Muzraeva, D. N. (2016) Buddiiskie i dobuddiiskie motivy v kalmytskoi skazke «72 nebylitsy» [Buddhist and preBuddhist motifs in the Kalmyk tale “72 fables”]. In: «Dzhangar» i epicheskie traditsii tiurko-mongol'skikh narodov: problemy sokhraneniia $i$ issledovaniia ["Dzhangar" and epic traditions of the Turkic-Mongolian peoples: problems of preservation and research]. Proceedings of $3^{\text {rd }}$ international conference. Ed. by T. G. Basangova, B. B. Mandzhieva and V. V. Kukanova. Elista, KIHR of the RAS. 324 p. Pp. 166-169. (In Russ.).

Ovshinov, A. N. (2020) Geroicheskii epos "Dzhangar" - filosofiia zhizni predkov kalmykov [Heroic Epic "Jangar" as Philosophy of Life of Kalmyks’ Ancestors.]. Humanitarians of the South of Russia, vol. 9, no. 2, pp. 234-248. (In Russ.). DOI: https://doi.org/10.18522/2227-8656.2020.2.17

Ondar, B. K. (2007) Toponimicheskii slovar' Tuvy [A toponymic dictionary of Tuva]. $2^{\text {nd }}$ ed. Kyzyl, Tuvan book publisher. 550 p. (In Russ.).

Ondar, M. V. (2016). Baza dannykh tekstov tuvinskogo geroicheskogo eposa: pervyi etap [Creating a database of Tuvan epic poetry: The introductory stage]. New Research of Tuva, no. 4, pp. 66-76 [online] Available at: https://nit.tuva.asia/nit/ article/view/616 (access date: 27.04.2020). (In Russ.).

Orus-ool, S. M. (2001) Tuvinskie geroicheskie skazaniia (tekstologiia, poetika, stil') [Tuvan heroic legends (textology, poetics, style)]. Moscow, MAKS Press. 422 p. (In Russ.).

Orus-ool, S. M. (2011) O perevodakh tuvinskogo geroicheskogo eposa na russkii iazyk [On translations of the Tuvan heroic epic into Russian]. In: Orus-ool, S. M. Izbrannye nauchnye trudy [Selected research]. Abakan, Zhurnalist Publishers. 296 p. Pp. 55-68. (In Russ.).

Orus-ool, S. M. (2018) Tengrianstvo v tuvinskom fol'klore [Tengrianism in the Tuva folklore]. International Tengri research Foundation [online] Available at: http://tengrifund.ru/tengrianstvo-v-tuvinskom-folklore.html (access date: 23.04.2020). (In Russ.). 
Ochir-Goryaev, V.E.(1978) Toponimika “Dzhangara” [Toponymics of “Dzhangar”].In: "Dzhangar” i problemyepicheskogo tvorchestva ["Dzhangar" and problems of epic creativity]: Proceedings of an International conference. Ed. by P. C. Bitkeev, E. B. Ovalov, B. B. Okonov. Elista, Kalmyk Institute of History, Language and Literature. 144 p. Pp. 130-132 (In Russ.).

Polyaev, V. O. (1978) Tibetsko-sanskritskie leksicheskie ehlementy v jazyke "Dzhangara” [Tibetan-Sanskrit lexical elements in the language of "Dzhangar"]. In: "Dzhangar" i problemy epicheskogo tvorchestva ["Dzhangar" and problems of epic creativity]: Proceedings of an international conference. Ed. by P. C. Bitkeev, E. B. Ovalov, B. B. Okonov. Elista, Kalmyk Institute of History, Language and Literature. 144 p. Pp. 98-100 (In Russ.).

Poppe, N. N. (1941) Ob otnoshenii Buryat-mongol'skogo Gesera k mongol'skoii knizhnoii versii [On the relation of Buryat-Mongol Geser to Mongol book version]. Zapiski GIIaLI. Ulan-Ude, Buryat-Mongolian state Research Institute of Language, Literature and History. Issue 5-6, pp. 7-19. (In Russ.).

Satanar, M. T. (2020) Ehksplikaciia nekotorykh kodov mifologicheskoii sistemy jakutskogo eposa olonkho (k postanovke voprosa o fol'klornom vremeni i prostranstve) [Explication of some codes of the mythological system of Yakut epic olonkho (towards the question of folklore time and space)]. Scientific dialogue, no. 6, pp. 302-319. (In Russ.).

Seleeva, C. B. (2019) Sjuzhetno-tipologicheskie osobennosti skazaniia “Bogdo Changgar khan” v tradicii tuvincev i eposa "Dzhangar" v nacional'nykh versiiakh kalmykov Rossii i oiiratov Sin'tziana [Subject and typological peculiarities of epic telling "Bogdo Changgar khan" in the tradition of Tuvans and epic "Dzhangar" in the national version of Kalmyks of Russia and Oirats of Xinjiang]. New Research of Tuva, no. 4, pp. 133-139. DOI: https://doi.org/10.25178/nit.2019.4.11 (In Russ.).

Skazki i predaniia altaiskikh tuvintsev [Fairy tales and legends of the Altaian Tuvans] (1994). Comp. by E. Taube. Moscow, Vostochnaya Literatura. 410 p. (In Russ.).

Spravochnik lichnykh imen narodov RSFSR [A guide to personal names of the peoples of RSFSR] (1979). Ed. by A. V. Superanskaia. $2^{\text {nd }}$ ed. Moscow, Russkii yazyk Publ. (In Russ.).

Torbokov, A. V. (2017) Buddiiskaia leksika altaiiskogo geroicheskogo eposa [Buddhist lexics of Altaic Heroic epic]. In: Aktual'nye problemy altaiiskoii dramaturgii v XXI veke: K 120-letiiu Pavla Kuchiiaka [Actual problems of Altai drama in the XXI century: To the 120th anniversary of Pavel Kuchiyak]. Materials of the Regional Scientific and Practical Conference]. Ed. by M. S. Dedina. Gorno-Altaiisk, Gorno-Altai State University Publ. 291 p. Pp. 267-275. (In Russ.).

Tuvinskie geroicheskie skazaniia: "Khunan-Kara”, "Boktug-Kirish”, "Bora-Shehleii” [Tuvan heroic tellings: "Khunan-Kara”, "Boktug-Kirish”, “Bora-Shehleii”] (1997). Comp. by S. M. Orus-ool. Novosibirsk, Nauka, SO Publishers. 584 p. (In Russ.).

Tuvinskie narodnye skazki [Tuvan folk tales] (1971) / transl. by M. Vatagina, preface to D. S. Kuular. Moscow, Nauka. 208 p. (In Russ.).

Tuvinskie narodnye skazki [Tuvan folk tales] (1994). Ed. by Z. B. Samdan. Novosibirsk, Nauka Publ. 460 p. (In Russ.).

Ulanov, A. I. (1957) K kharakteristike geroicheskogo eposa Buryat [On the characterization of the heroic epic of the Buryats]. Ulan-Ude, Buryat-Mongol book Publ. 171 p. (In Russ.).

Ulanov, A. I. (1963) Buryatskii geroicheskii epos [Buryat heroic epic]. Ulan-Ude, Buryat book Publ. 220 p. (In Russ.).

Florensov, V. N. (1927) Mongolo-Buryatskaia skazka o Mehrgehn-Zorikto. [Mongol-Buryat tale about Mehrgehn-Zorikto]. Irkutsk, Vlast' truda Publishers. 16 p. Otdel'nyii ottisk iz vyp. XII Sbornika trudov Irkutsk. gosud. un-ta, pp. 237-250. (In Russ.).

Khabunova, E. Eh., Gedeeva, D. B. and Ubushieva, B. Eh. (2018) Toponimy v fol'klornom kontekste kalmykov [Toponims in the folklore context of Kalmyks]. New Research of Tuva, no. 3, pp. 242-258. DOI: https://doi.org/10.25178/ nit.2018.3.16 (In Russ.).

Khabunova, E. Eh., Dampilova, L. S., Kungaa, M. B. and Aiuushzhaviiin, A. (2019) Tuvinskoe skazanie "Bogda Changar khan" i ego konstantnye segmenty v oiiratskoii i kalmyckoii versiiakh geroicheskogo eposa "Dzhangar" [Tuvan telling "Bogda Changar khan" and its constitutive segments in the Oirat and Kalmyk versions of heroic epic "Dzhangar" ]. New Research of Tuva, no. 4, pp. 109-118. DOI: https://doi.org/10.25178/nit.2019.4.9 (In Russ.).

Khaltueva, G. O. (2009) Toponimicheskii leksikon «Sokrovennogo skazaniia mongolov» $i$ «Kodziki»: obshchee $i$ chastnoe [Toponymic lexicon of the "Secret History of the Mongols" and "Koiiki": the general and the particular]. Abstract of Diss. ... Candidate of Philology. Ulan-Ude. 25 p. (In Russ.).

Khangalov, M. N. (2004) Sobranie sochinenii [Collection of papers] : in 3 vol / ed. by N. Rumjanceva. Ulan-Ude, Respublikanskaia tipografiia Publishers. Vol. 3. 312 p. (In Russ.).

Khertek, L. K. (2015) K voprosu o lingvisticheskom analize epicheskikh tekstov [To a question on the linguistic analysis of epic texts]. Philological sciences. Questions of theory and practice, no.12 (54): in 4 parts. Part I, pp. 188-190. (In Russ.). 
Khomushku, O. M. (2006) Religioznyi sinkretizm u narodov Saiano-Altaia [Religious syncretism among the peoples of Sayan-Altai]: Abstract of Diss.... Doctor of Philosophy. Moscow. 53 p. (In Russ.)

Tsybenova, B. B. (2000) Obschnosti i razlichiia Buryatskogo eposa "Geser" i kalmyckogo eposa "Dzhangar" [Commonalities and differences between the Buryat epic "Geser" and the Kalmyk epic "Dzhangar"]. Diss ... Candidate of Philology. Ulan-Ude. 162 p. (In Russ.).

Tsyrempilov, N. V. (2013) Buddizm i imperiia: Buryatskaia buddiiskaia obschina v Rossii (XVIII - nach. XX v.) [Buddhism and Empire, Buryat Buddhist community in Russia (XVIII - the beginning of. XX cent.)] / ed. by B. V. Bazarov. UlanUde, IMBT SB RAS. 338 p. (In Russ.).

Chingeltei, B. (2004) Vliianie buddiiskoi literatury na epos "Dzhangar” [The influence of the Buddhist literature on the epic "Dzhangar"]. In: "Dzhangar" i problemy epicheskogo tvorchestva ["Dzhangar” and problems of epic creativity]: Proceedings of an international conference. Ed. by P. C. Bitkeev and E. B. Ovalov. Elista, Dzhangar. 602 p. Pp. 318-324. (In Russ.).

Sharakshinova, N. O. (1987) Geroiko-epicheskaia poehziia Buryat [Heroic epic poetry of Buryats]. Irkutsk, Irkutsk University Publ. 304 p. (In Russ.).

Shoiinzhonov, B. B. (2008) Otrazhenie religiozno-kul'tovykh predstavlenii v Buryatskom fol'klore [Reflection of religious ideas in Buriat folklore]. Abstract of Diss.... Candidate of Philology. Ulan-Ude. 27 p. (In Russ.).

Submission date: 10.05 .2020 . 